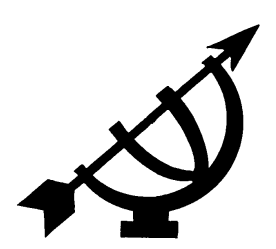

\title{
Knowledge for sale? The impact of a consumerist hermeneutics on learning habits and teaching practices in higher education
}

\author{
E.M. Conradie \\ Department of Religion \& Theology \\ University of the Western Cape \\ BELLVILLE
}

E-mail: econradie@uwc.ac.za

\begin{abstract}
Knowledge for sale? The impact of a consumerist hermeneutics on learning habits and teaching practices in higher education
\end{abstract}

The impact of the commercialisation, if not the corporatisation of higher education institutions in a globalised economy, has been widely discussed in recent literature with regard to the ethos of institutions, management, research, as well as teaching and learning. Indeed, in the 'knowledge industry' knowledge is offered for sale. This article makes a contribution to this discourse by exploring the impact of consumerist hermeneutics on the basis of critiques of consumerism in Christian discourse, drawing especially on the work of Vincent Miller, 'Consuming religion' (2003). The notion of consumerist hermeneutics is related to the impact of culture commodification in a consumer society. Given the overload of information, consumers have to adopt shallower forms of attention as a survival strategy. If such a shallower engagement is applied to virtually all cultural products, this leads to a reductionist understanding of knowledge. The impact of such consumerist hermeneutics on learning habits and teaching practices in undergraduate university education is then discussed briefly. In conclusion, some possibilities for resisting the hegemony of a consumerist ideology are noted. 


\section{Opsomming}

\section{Kennis te koop? Die impak van 'n verbruikershermeneutiek op studiegewoontes en onderrigpraktyke in hoër onderwys}

Die impak van die kommersialisering en korporatisering van hoëronderwysinstellings in 'n geglobaliseerde ekonomie word wyd bespreek in eietydse literatuur, met betrekking tot die etos en bestuur van instellings, navorsing, leer en onderrig. In die sogenaamde kennisindustrie word kennis te koop aangebied. Hierdie artikel lewer 'n bydrae tot hierdie diskoers deur die impak van 'n verbruikershermeneutiek te ondersoek op grond van Christelike literatuur oor die verbruikerskultuur, met spesifieke verwysing na die werk van Vincent Miller in 'Consuming religion' (2003). Die konsep 'verbruikershermeneutiek' hou verband met die kommodifisering van kultuur in 'n verbruikersamelewing. Verbruikers word gedwing, gegewe die oorlading van inligting, om vlakker vorms van aandag te benut as 'n oorlewingstrategie. Indien sodanige vlakker aandagvorms op alle kulturele produkte toegepas word, lei dit tot 'n reduksionistiese begrip van kennis. Die impak van sodanige verbruikershermeneutiek op studiegewoontes en onderrigpraktyke in voorgraadse universiteitsonderrig word op grond hiervan ondersoek. Verskeie moontlikhede om weerstand teen die hegemonie van die verbruikersideologie te bied, word ten slotte genoem.

\section{Introduction: the commercialisation of higher education}

Arguably, financial considerations play an increasingly decisive role in managing universities in South Africa and elsewhere in the world. This change in focus may be regarded as necessary, prudent, and in the interest of sound financial management of any institution, universities included. However, in the context of a globalised economy, this also opens the door for what may be called the commercialisation 1 or corporatisation of higher education, with many farreaching implications.

1 For the use of this term, see especially Mamdani (2007:118-119). He makes a distinction between privatisation and commercialisation. He explains:

Privatisation was an external relationship between the market and the university, whereby the university opened up its gates to fee-paying students but did not change the curriculum to suit the demands of the market. Commercialisation, however, led to a deep-seated transformation, involving not only the external relationship between the university and the market, but also the internal process of knowledge production in the university and internal relations between different academic units. The university opened its gates to fee-paying stu- 
Accordingly, universities are portrayed as businesses offering knowledge packaged and branded in the form of teaching programmes for sale to interested clients. In an age of digital communication technology this is epitomised by on-line courses and degrees, which focus on training and the delivery of skills-oriented products. On this basis consumer demand is measured in terms of the number of applications, student registrations (full-time equivalents), student throughput, and the income generated on this basis in terms of subsidy. At state-funded universities, where income is derived mainly from student numbers, both in terms of tuition fees and government subsidies, this logic seems inescapable.

This portrayal of universities as corporations offering knowledge and training for sale is, of course, highly reductionist. Neither knowledge itself, nor the value of knowledge can be easily quantified and on that basis be reduced to financial transactions - in the same way that the value of friendship, love and children cannot be expressed merely in economic terms. Gaining knowledge involves more than purchasing products or acquiring skills; it also entails the deliberate process of developing disciplines and academic virtues - that cannot be merely purchased on-line. There hopefully remain some teachers and students who have not failed to recognise that knowledge cannot be translated into "quantities of information" and is "more" than a product for sale, despite the pressures of corporatisation and commercialisation.

However, what that "more" entails is a subject of ongoing dispute. The classic philosophical debate has lost none of its significance: Is knowledge essentially a form of virtue or of power? It is the subject of ongoing philosophic inquiry about the very nature and purpose of a university, 2 the discourse on academic freedom in relation to other institutions (especially the state, but now also other corporations) and the need for social transformation in line with changing national goals, priorities and needs. Whatever that "more" may be deemed to

dents, commercialised relations between teaching units and embarked on changing its curriculum by introducing market-driven programmes. 
be, many scholars may wish to concur with the gist of the provocative title of Bills Readings' book, The university in ruins (1996). The "more" is being eroded with grave consequences for the very nature of a university.

The dangers of such reductionism have often been identified, perhaps especially in the sphere of the humanities where it is widely recognised that the value of philosophy, poetry, arts, history, culture and religion cannot be measured in purely financial terms. In a recent special issue of the Journal of higher education in Africa, aptly entitled "From ivory tower to market place" (Weinberg \& Kistner, 2007), the editors observe that "Such is the magnitude of the current crisis, so radical the changes, and so deep the bewilderment experienced by academics" that the very raison d'etre of the university is at stake. They continue to explain what is at risk:

University transformation, it turns out, is enmeshed in a complex web of interrelated processes that have long taken it out of the ambit of what the anti-apartheid struggle had once envisaged as a socially and politically transformative educational agenda. Instead, transformation has become aligned with the commercialisation of education, with restructuring and rationalisation and, in post-apartheid South Africa, with conflicting directives of Africanisation, employment equity, job creation and poverty alleviation. This marks one of the peculiarities of South African post-apartheid higher education. On the one hand, the state's policies have created openings for the play of market forces in tertiary education, creating conditions for corporate managerialism; on the other hand, they are advocating redress and curriculum development. (Weinberg \& Kistner, 2007:1.)

There are various areas where criticisms against the commercialisation and corporatisation of education may and indeed have been expressed in secular literature on higher education:

- Firstly, education becomes a matter of providing "knowledge products" and training in line with the needs of the job market and thus of the design, marketing and delivery of such products to paying clients. The "knowledge industry" is classified under the service sector of the economy and is indeed one of the most lucrative of all services (Vally, 2007:24). This implies that the provision of education becomes dominated by cost reduction and efficiency. Students therefore become consumers and lecturers sales consultants (Vally, 2007:20; Weinberg, 2007:73). The redefinition of knowledge assumes that it can be packaged in terms 
of quantities of information, and that the input of students can likewise be quantified and measured as units of labour (notional hours of student learning time). The commodification of knowledge that is thus packaged depends on the ability to reproduce such products according to unit standards. However, what is consumed here is often not so much the product itself (knowledge), but the associated values attached to the product through branding (prestige, aspirations, a ticket to success, having "a good time", meeting influential people, finding a marriage partner, etc.)

- Since student interest typically forms the basis for the allocation of academic posts, there is a "capital flight" from the humanities and a decline in their "market share". If this criterion is applied consistently, a number of academic disciplines - most notably philosophy - would be likely to dwindle and eventually be eradicated. The need for subsidisation across faculties and across disciplines within a faculty is countered by competition between faculties and disciplines. In the corporate model of education it is indeed a matter of the survival of the fittest.

- The corporatisation of universities has coincided with a managerial ethos where administrators are appointed who understand the ways and means of financial management, the demands of social transformation (including Africanisation), 3 and the need for efficiency and "excellence", 4 but not necessarily the pursuits of research and teaching. Moreover, the social goals of education are often brought in line with corporate or national interests.

See the article by Weinberg (2007) on the tensions between the demands for social transformation and the corporatisation of universities, albeit that both processes rely on managerial restructuring and tend to inhibit academic leadership. See also the comment by Kistner (2008:96):

The 'transformation' in higher education is unmasked as commercialization and corporatization. The transformation of African universities is effectively one 'from sites of knowledge production to sites of hotel construction: from building lecture halls to pre-fabricating shopping malls'; 'from the culture of collegiality' to 'the thick of corporate vultures'. Academic concerns are now centering on manipulation of mark sheets to show passes.

... that the previous connotation of 'excellence' as the highest conceivable standard of scholarship and research has been displaced by a notion of 'excellence' that shows assiduous regard for evaluative devices and machineries rather than the didactic component of course content. 
- Such corporatisation may well imply that the social transformation of higher education is sidelined or at least in conflict with financial considerations. Academic support programmes are cut since students from disadvantaged backgrounds are costly and not necessarily successful, while programmes with greater purchase in the marketplace are privileged (Vally, 2007:20).

- Research and especially the identification of research topics have become largely driven by financial considerations. As Jansen (2006:19) observes, "the accumulation of larger and larger numbers of accredited publications is pursued with relentless vigour". This applies to major sources of funding from the National Research Foundation (where national priorities have been outlined), but also to lucrative funding available from the corporate world and from international research agencies. While such research funding is clearly attractive, there is an obvious danger that universities will become subservient to corporate, pharmaceutical and military agendas, for example in the areas of manufacturing weapons, biotechnology and nuclear energy. Such research may be prompted by social needs (e.g. in the field of HIV and AIDS and health), but given the gigantic sums of money available, researchers and their corporate sponsors may well have a vested interest in the trauma of others. Given such priorities there is a steady erosion of research support for the humanities unless such research is done on specified topics related to national priorities. A generic competence in theory, history and advanced literacy - which forms a necessary requirement to address social needs - seems to be taken for granted and is, therefore, not readily supported (cf. Higgins, 2007).

- Universities are Pelagian institutions where one is "saved" on the basis of good works alone. This is of course entirely appropriate in the sense that students should pass examinations and be awarded degrees on the basis of their performance. The slogan Pass one, pass all would necessarily undermine the value of tertiary education. However, an extension of this towards a capitalist ethos can have devastating consequences for academic life. Where the values of competition, hard work, achievement and financial gain are carried to the extreme, these would undermine critical collegiality, open inquiry and the joys of a contemplative life. As Readings suggests, a university is a "community of dissensus", a view of community "that abandons either expressive identity or transactional unity as a means to unity" (Readings, 1996:192; quoted in Stewart, 2007:143). 
Knowledge may indeed be power but in circumstances where it becomes measured in terms of financial power alone, the virtue of gaining knowledge for the sake of intellectual curiosity, expanding the frontiers of knowledge, transferring such knowledge to a next generation, and for serving the needs of society would be undermined. Only on this basis can academic programmes be brought in line with community needs and struggles.

On this basis one may argue, with Jonathan Jansen, that the autonomy of higher education institutions may be jeopardised through funding formulae and legislative intervention - in the name of social transformation. Jansen (2006:19) says:

A university ceases to exist when the intellectual project no longer defines its identity, infuses its curriculum, energises its scholars, and inspires its students. It ceases to exist when state [...] interference closes down the space within which academic discourse and imagination can flourish without constraint. The university ceases to exist when it imposes on itself narrowing views of the future based on ethnic and linguistic chauvinism, and denies the multiplicity of voices and visions that grant [such] institutions their distinctive character. And the university ceases to exist when it represents nothing other than an empty shell of racial representivity at the cost of academic substance and intellectual imagination. (Quoted in Weinberg, 2007:67.)

In this contribution I wish to highlight another aspect of such reductionism, namely the impact of a consumerist hermeneutics on learning habits, and subsequently also on teaching practices. I will draw on Christian discourse on consumerism 5 and endeavour to make it relevant to the South African discourse on the commercialisation of higher education.

\section{A consumerist hermeneutics}

In his groundbreaking work Consuming religion (2003), Miller points out that the underlying challenge posed by a culture of consumerism is related to the commodification of culture, values and beliefs. Such commodification leads to what may be described as "shallow engagement" with consumer products. In this section I will draw on Miller's work in order to describe the consumerist hermeneutics that

5 See the review of Conradie (2009) of the literature and an analysis of six points of entry for a critique of consumerism. The following section of the article builds upon chapter 6 of that book. 
results from such shallow engagement. I will use the term consumerist hermeneutics to refer to reflection on the interpretative habits shaping a consumer society.

Miller draws from Marxist theory to describe the process through which factory workers have become alienated from the products that they produce. Compared to artisans, such workers often do not see the end product of their labour. Alienated labour is undertaken only because it is regarded as necessary to obtain the wages required for survival. Such wages are used to purchase various commodified products. Food, for example, is purchased and crudely consumed in a manner that is removed from traditional rituals of planting, harvesting, preparation and sharing a meal. The origins of commodified products can no longer be traced back to a particular context. This is epitomised in a globalised economy where different parts of a product may be outsourced from a wide variety of contexts (where labour costs are lower and environmental regulations fewer). This implies that the end product becomes a fetish, devoid of meaning, only assessed in terms of its exchange value; it appears on the shelf of a supermarket without traces of the raw material, labour, skills, technology, capital and transport required to make such a product available. Its value is understood in terms of its exchange value compared to other commodities (Miller, 2003:23 ff.).

In a consumer society the hermeneutical vacuum that results from the systematic evacuation of meaning in the process of commodification is typically filled by industrial design, the aesthetics of style and fashion, marketing, and packaging (Miller, 2003:38 drawing on insights from Sut Jhally). The production of meaning through marketing is not, however, geared to explain the production processes. Instead it is geared to brand the product in a particular way and provide a range of connotations that may be attractive to potential consumers. The work of the French cultural critic Jean Baudrillard is influential here: what is being consumed is not merely the material product but a differentiated system of cultural meanings branded unto commodities. Admittedly, given consumer resistance against fascist propaganda and social engineering, marketing is unable to create such meaning and enforce it on consumers. Instead, the task of marketing is to spot the latest trend and mobilise meaning by attaching it to a particular product, typically on the basis of getting a celebrity or sport hero to underwrite the product (Holt \& Schor, 2000:xx).

Moreover, marketing agencies also exploit a therapeutic dimension to consumer products: through marketing, consumption is often as- 
sociated with psychological and social needs that were previously met through family life, friendship, community life and religious adherence (which formed part of production processes). There are many examples: buying a particular brand of tea would make you a good neighbour; this soap product will ensure that you are a good mom; this car would restore a dad's relationship with his teenage son; and this body oil will enhance your own self-esteem. In each case one is told that you are entitled to a certain product simply because you are worth it. Miller (2003:88) comments that it is impossible to overstate the significance of this shift. "The massive cultural force of advertising directed people to fulfil their needs for meaning, wholeness, and belonging through consumption." Through misdirection consumers are encouraged to fulfil more profound needs through cruder forms of consumption. A trip to the shopping centre where I can spoil myself consequently becomes a form of (retail) therapy, a cure for depression. Accordingly, shopping is not merely a shallow expression of greed but of the need for community and wholeness. This also implies that the symptoms of consumerism cannot be remedied if the underlying human needs for identity and community are not addressed.

This has significant implications for the way in which consumers engage with consumer products. Firstly, the branding of a product may become more significant than the usefulness of the product. What consumers thus appropriate is the cultural and symbolic meaning of the product.6 As Juliet Schor (2000:456) observes, the realm of consumption "is a dream world where fantasy, play, inner desire, escape and emotion loom large".

Secondly, given the technological complexity of many commodities (canned food, pencils, but certainly most household appliances), consumers find it impossible to be knowledgeable about the contents of each product (there are some exceptions with health foods). Such complexity provides an opening for the manipulation of needs and desires through advertising (Miller, 2003:120 drawing on insights from William Leiss). This allows for the selection of consumer goods on the basis of their emotional appeal - which is easily exploited through marketing.

6 Critiques of advertising suggest that it encourages crass materialism and are, therefore, misplaced. If anything, one may argue that precious material things are under-valued and over-spiritualised through what is associated with it. See also Schudson (1998:253-254). 
Thirdly, given the oversupply of consumer goods, consumers are confronted with an overload of information and advertising appeals on their purchasing power. A single outing to the supermarket requires a myriad of choices and also trains us in the mental habits of commodification. You have to select one among the many available brands of toothpaste that compete for your attention, not to mention all the food products. This array of promised pleasures serves as a horizon of seduction within which each consumer is situated (Miller, 2003:124-125).

Fourthly, this overload necessitates a form of shallow engagement with each product. This shallow engagement is manifested in terms of the production processes, the selection of consumer goods and often the act of consumption itself. This is perhaps epitomised by a branded burger in a fast food outlet, consumed in a hurry, often standing or even walking to a next appointment while "grabbing a bite". This may be contrasted with a lengthy family meal where food is produced in one's own vegetable garden, prepared in one's own kitchen, and consumed in the company of family and friends at leisure.

Fifthly, the regular practice of glancing through an overload of advertised goods is significant, not only because it shapes the desires of consumers, but also because it influences their interpretative habits. Since consumers are trained to find fulfilment through consumption, they are also being trained to apply the interpretative habits of consumption to other pursuits, including, as I will argue below, academic studies.

It should be noted that the commodification of products is in many ways convenient and, therefore, attractive for consumers. Given the fast tempo of urban life and multiple appeals to one's attention, one simply cannot afford to engage thoroughly with every consumer product. Moreover, the processes of commodification are no longer geared at a homogenous mass culture, but increasingly at a segmentation of the market and the identification of niche markets. Mass production is no longer so "massive"; flexible production technologies allow a proliferation of customised products and therefore more consumer choice and "creativity". One example of this would be consumer choice between a wide array of television channels to cater for each and every need (Miller, 2003:70).

The problem emerges in instances where the process of commodification is extended towards cultural products. In a consumer culture almost anything can become commodified and branded in 
this way: news flashes, music, knowledge, education, human bodies, voyeuristic sexual encounters, sport, entertainment, acts of violence (including cartoons and media reports on war), holidays and religion. In the next section I will return to the theme of the commodification of knowledge. The examples of sex and work as commodities may illustrate what is at stake here:

- The problem with sex as a commodity is not merely that the human body is reduced to an object of consumption through pornography and prostitution, that it serves as a utility to market other commodities (where satisfaction is implicitly promised but never realised), or that it reinforces chauvinist constructions of gender (rendering legitimacy to violence against women). The problem is also that all too many other forms of intimacy - which may be expressed through sexual communication and that require reciprocity and mutual consent - become shallow forms of consumption, typically isolated from the network of social relations in which the sexual partners are embedded, and disconnected from kinship and belief systems. In this way sex becomes little more than a sport where tenderness is replaced by certain techniques that have to be mastered and where the quality of human relationships is sacrificed for the sake of erotic pleasures, which ultimately fail to satisfy the human need for intimacy (Kavanaugh, 2006:56-63). 7 As Tim Gorringe (1994:153) comments, "In the advertising culture it is no longer 'man' who is the measure of all things, but sexual orgasm."

- Remarkably, even jobs can be commodified. In a consumer culture work must preferably be meaningful and exciting, certainly not boring. Admittedly, such job satisfaction remains a highly coveted prerogative of a privileged few (who are, therefore, susceptible to becoming workaholics). Consumer habits are thus applied also to employment: work is not merely a form of production but now also of consumption. Vocation is inverted towards vacation. Vacations are of course needed to counter the competitiveness of employment conditions, but the tempo of luxurious holidays provides no escape from the relentless world of work.

In a consumer society almost anything can be commodified, and as a result, almost everything is indeed commodified. The relentless

7 Kavanaugh (2006:62) comments that such commodification of the human body correlates with a form of planned obsolescence for marriage relationships. The average marriage lasts scarcely longer than the average car! 
drive to commodify is also evident in the commercialisation of public space. The observations of Holt and Schor (2000:ix) from within an American context are worth quoting at some length:

Advertising and marketing appear almost everywhere - in museums, on public television and radio, in doctor's offices, on subway platforms, and on restaurant menus. Sports arenas, previously names for communities, now sport corporate logos. Movies are replete with product placements. Public schools, once relatively isolated from corporate advertisers, became their new frontier during the 1990s, as marketers strived for 'share of mind' among six-year-olds. Many of the nation's children now watch commercials in their classrooms (via Channel One), learn from corporate-written curricula, look at advertising on the Internet, or drink the official school soft drink (Coke or Pepsi). Indeed, our deepest personal connections are increasingly dominated by market transactions, whether it's through surrogate motherhood, the sale of one's DNA, the booming trade in sex for hire, or the commercialization of religion and spirituality. Little remains sacred, and separate from the world of the commodity. As a result people become ever more desperate to sacralize the profane consumer world around them, worshipping celebrities, collections and brand logos.

A consumer culture may therefore be defined as a culture in which various cultural elements are readily commodified (Miller, 2003:72). Accordingly, consumer practices, derived from the consumption of supermarket products, are often applied to cultural products as well. This implies that the engagement with cultural products mirrors the hermeneutic employed for consumer products and not the other way around. The shallowness of a consumerist engagement with cultural products leads to a reduction and a hollowing out of the potential value richness of the product. Even that would not be problematic unless such a shallow engagement is applied to virtually all cultural products. Zygmunt Bauman (2000:73) suggests that this is exactly the case. The archetype of our cultural engagement is shopping.

If shopping means scanning the assortment of possibilities, examining, touching, feeling, handling the goods on display, comparing the costs with the content of our wallet or our remaining credit limit and putting the item in our cart or back on the shelf - then we shop outside stores as much as inside; we shop in the street and at home, at work and at leisure, awake and in dreams. Whatever we do and whatever name we attach to our activity is a kind of shopping, an activity shaped in the likeness of shopping. 
Two aspects of such a shallow engagement may be mentioned here, namely the ways in which attention to such cultural products is structured (and the time allocated in the process), and the disconnection between cultural practices, values and beliefs.

Firstly, it should be noted that an urban, industrial environment requires a highly complex network of relations. In a homogenous rural community people would need to engage with a relatively limited number of role players and impulses. By contrast, in an urban context one's path would cross with numerous people and one is confronted with an overload of claims to attention. This is indicated by the multiplicity of advertisements, billboards, news flashes, incoming e-mails, products on the supermarket shelf, books and magazines available in the library, requests for assistance and participation, et cetera.

This observation leads German ethicist Günter Thomas to suggest, precisely as a result of an overflow of media products, that human attention has become one of the scarcest and most contested (cultural) resources. 8 In such a context one simply cannot attend to all (media) claims to attention - selectivity is the key to survival. Given such an overload of claims to attention, the temptation is there to pay relatively brief attention to not only some but to virtually all such claims. One example would be the "quality time" that busy parents wish to spend with their children - but which is all too often threatened by multiple other demands (besides not being available when children need their parents on the children's terms). The result is not only shallow forms of cultural engagement but complaints about being always too busy and trying to do too many things without doing any one thing properly (a complaint regularly heard

8 See the essay by Günter Thomas (2004) on "The cultural contest for our attention: observations on media, property, and religion". Thomas (2004:285) observes that the increase in the possibilities for communication and the related decrease in the availability of human attention constitute a dramatic cultural shift. The only way to address the scarcity of attention is to amplify demands on attention - and as a result to exacerbate the problem of scarcity. He adds the very interesting observation that attention has become a form of currency for advertisers. People do not pay directly for communication services such as newspapers, television or internet search engines. Instead, these communication services attract advertisements because of their ability to engage the attention of their users (which is what attracts advertisers). Payment for communication services by the consumer is, therefore, not in hard currency but in a willingness to allocate one's attention to a particular media product (Thomas, 2004:286). This is the result of the cultural drive to consume more information than what people can pay for in money. 
among lecturers). The key to deeper forms of engagement would lie in the process of selection (and the discernment that requires), in time allocation (discerning how much time a particular claim to one's attention requires), and in the nature of the attention given (ranging from mere awareness, perceptive attention, self-reflexive attention and reciprocal communicative attention) (Thomas, 2004:278). All too often the process of selection itself can become all-consuming while "paying" attention can indeed become a scarce commodity. In an advertisement-driven culture there is a tendency to reduce reciprocal communicative attention to perceptive attention, as elicited mainly by audio-visual media - we receive and perceive impulses without responding to such impulses in a communicative process (Thomas, 2004:284). In the midst of a commodification of attention there is a need to foster and regenerate skills of attention. Both Miller and Thomas suggest that the liturgy is one way through which such skills can be regenerated.

Secondly, as Vincent Miller (2003:32) notes, the commodification of cultural products allows consumers to engage with elements of culture as free-floating signifiers, put to decorative uses far removed from their original connections with other cultural practices, values and beliefs. This is more or less necessitated by the need for exchange on the cultural market - since exchange requires interchangeability, a rough equivalence where products may be compared with one another (Miller, 2003:77). When this occurs we tend to watch TV in the same way that we glance at advertisements, and we tend to engage with social and political processes in the way that we watch TV - as passive consumers and at a distance. ${ }^{9}$ Then we might as well engage with sermons and religious practices in much the same way. This shallow engagement is perhaps epitomised by a holiday tour where tourists hop from one city to the next, taking snapshot pictures everywhere, but taking in little of the history and culture of the place visited. Miller accordingly concludes that consumerist habits of interpretation and channels of communication allow religious believers to encounter religious material disconnected from shared religious practices.

Miller observes that counter-cultural movements are also easily commodified in a consumer society. Even the most stringent critique

9 Daniel (2005:23) comments on the impact of such passivity of children's education: "Where once Lego building blocks encouraged creativity, they now come in specific kits with instructions on building the item pictured on the cover." 
of a consumer society (for example Marx's Das Kapital) may be branded and sold on the market of ideas (as a paperback or, if you prefer that, a leather-bound special edition). In my discipline this would also apply to any theological critique of consumerism. It would help relatively little to retrieve some apparently-forgotten Christian symbol - since such a retrieval will simply add to the plethora of products on the market of resources for a cultural critique. Indeed, given such commodification of dissent, there is little escape from the pervasive process of commodification in a consumer society. A response to consumerism cannot be based on ideas alone since the material processes that shape the production of meaning (including culture and religion) in a consumer society have to be accounted for.

The commodification of culture also allows for a commodification of religion. This is expressed in the ambiguous title of Miller's book, Consuming religion. Religious "products" thus become available on the "market" of ideas together with other cultural products. In the same way that other products become disconnected from production processes, when religious beliefs (whether Christian or otherwise) are commodified, they become disconnected from the communities and their practices that sustain such beliefs. Miller (2003:3) notes that:

Elements of religious traditions are fragmented into discrete, free-floating signifiers abstracted from their interconnections with other doctrines, symbols and practises. This abstraction of elements from their traditions weakens their ability to impact the concrete practices of daily life. Deprived of their coherence with a broader network of beliefs, they are more readily put to other uses, as shallow signifiers of whatever religious sentiment we desire.

As a result, religious beliefs are diversified, demonopolised and in the process trivialised (rendered ineffectual).

This also truncates the potential of such religious beliefs to shape one's own culture. Instead, people apply the consumer practices that they have acquired in the dominant culture to religious products as well. This implies a shallow engagement with such religious products - as passive consumers - more or less in the same way that a music DVD emanating from a culture very different from one's own may be purchased and consumed without much engagement with the worldviews, practices and values embedded in that culture. In 
short, the religious practices that sustain religious beliefs are substituted by consumerist practices that undermine such beliefs. 10

The interchangeability of such religious products invites a shallow form of bricolage, a mix and match of elements to create one's own religious pizza as it were. This also leads to a situation where the differences between religious traditions are underplayed and people tend to view them merely as different versions (brands) of the same product (e.g. toothpaste). As Gregory Jones (1997:15) observes: "This consumer mentality also suggests a levelling of diverse religious traditions: they become brand names selling essentially the same product with slightly different packaging."

It should be noted that the inverse of such a marginalisation of religious beliefs may also take place wherever religious practices become fully commercialised. In such a context religious products may themselves become valuable commodities that would allow for lucrative business opportunities - especially in the form of gospel music, religious videos, magazines and a plethora of popular religious publications. Alternatively, and perhaps more effectively, religious beliefs may also be used to legitimise consumerism and the newliberal capitalist economy within which it thrives. This is most clearly expressed among churches where a "prosperity gospel" is preached - which serves to sanction the upward social mobility of their members in a consumer society. In both cases religion can become extremely influential, albeit that such religious practices are fully encapsulated within a consumer society.

\section{Knowledge and learning habits}

On the basis of the description of a consumerist hermeneutics, I now wish to offer some observations on the learning habits of undergraduate students in a consumer society such as contemporary South Africa. These observations are not based on empirical research; instead they are drawn from personal experience and aimed at inviting critical discourse among academics involved in undergraduate teaching, and hopefully at stimulating such empirical research by formulating possible hypotheses.

10 See Miller (2003) on the ways in which the habits of consumption transform religious practices through the commodification of culture, values and beliefs. His approach is novel in that he refrains from offering a critique of the consumer society. Instead, he focuses on the impact of consumer society on religious beliefs and practices. 
First of all it should be noted that university students acquire their learning and interpretative habits from a range of activities in which they are called to interpret the meaning of signs. These include shopping in the normal sense of the word (in the sense of selecting products from a supermarket shelf), but also in the sense of shopping for other products such as leisure activities and selecting television channels. In addition, one may mention browsing through advertising columns, passively absorbing televised products, paging through newspapers and glossy magazines, and browsing on the internet. Students seldom read novels, not to mention poetry, history or other forms of non-fiction. The point is that these activities shape their interpretative habits.

Secondly, a number of features of such interpretative habits may be identified. These modes of interpretation largely encourage a passive registration of communicated products. Communication and interpretation is of course never purely passive, but in many cases the initiative is not taken by the receiver. A well-constructed response is typically not required. The products received are pre-packaged in small units (bite-size chunks) that can easily be assimilated and allocated. As a result, the demands placed on an interpreter are not particularly heavy. Here the cultural impact of numerous magazine articles and self-help literature providing "five easy steps to ..." should be mentioned specifically. These typically lead to a shallow engagement with media products. There is also a tendency to move from one media product to the next in rapid succession. This encourages a consumerist ethos where immediate gratification is the watchword. Delayed gratification that follows from an extensive and more detailed engagement with demanding material would be frowned upon. Given the overload of information inputs, interpreters find a need to protect themselves from the excessive demands on their attention. As a result, there is an emotional resistance against allocating significant time to any one task or any one text.

Thirdly, it should also be noted that the value of gaining knowledge is thus seen in terms of a consumerist ethos. Even where the need for delayed gratification is acknowledged (a degree only after three years), the emphasis would still be on gratification. Kavanaugh (2006:46-49) observes that the commodification of knowledge has far-reaching consequences, since all forms of knowledge (including wisdom, insight, knowledge of persons) are reduced to the kind of knowledge that we have of consumer products. We become consumers of knowledge and we are no longer enhanced by it 
(Kavanaugh, 2006:65).11 Knowledge is, therefore, consumed for the sake of self-gratification. Knowledge is not a form of virtue or power but of pleasure!

Here the ideological features of a consumerist culture should be recognised. Gaining knowledge is seen as a means to an end that may be described in terms of the categories of hedonism, pleasureseeking, self-fulfilment, narcissism, and so forth. Ted Peters (1980: 32) observes that the insatiable demands of the consumer class lead to the habit of moving sponge-like through life, sopping up one experience after another, soaking in rich food, marvellous media spectacles, exciting travel to ever more remote destinations, thrilling risks, gambling on the stock exchange, sexual pleasure, and even religious ecstasy. However, the problem is that a repetition of an experience of pleasure soon fades away to a feeling of mild contentment and then to boredom. As a result, hedonism can become a form of opiate to relieve boredom. Sallie McFague (2001:93) comments: "We enjoy the consumer lifestyle; in fact we are addicted to it, and, like addicts, we cheerfully stay in denial if possible."

Gaining knowledge is thus seen as an extension of this pursuit for gratification. In crude terms this would imply that students study and gain knowledge in order to obtain a degree, that they wish to obtain a degree in order to secure attractive employment, and that the remuneration for such a position is regarded as essential in order to maintain a desired (consumerist) lifestyle. Accordingly, gaining knowledge is not regarded as an aim in itself, but as a means to another end. This attitude to academic studies may well be taken completely for granted by the current generation of students, although there are of course (hopefully!) many exceptions.

Fourthly, it should be evident that these interpretative habits would lead to an inability among students to focus on demanding texts, to read longer texts with an extended argument, and to construct a detailed, coherent response to prescribed texts. In fact, one may find a widespread cultural resistance against an overload of information, against too many demands on one's attention and on being required to focus intensively and extensively on any one task. While this may

11 Kavanaugh (2006:49) comments that we become obsessed and possessed by such commodities:

Trusting most whole-heartedly in commodity-formed knowledge, we begin to understand and recreate ourselves in the image and likeness of the products of our hands. 
have been criticised as "laziness" by lecturers in a previous generation, such learning habits should also be understood as deeply embedded in the cultural world of contemporary students. Of course, technology-aided forms of teaching may be used that do require a written response from students, but this is not often based on an engagement with longer prescribed texts.

\section{Teaching-learning processes}

Where students come to a university with the interpretative habits defined by a consumerist hermeneutics as outlined above, this would necessarily have an impact on teaching practices. Often lecturers would have acquired their interpretative habits in a previous generation and would be confronted with severe difficulties in communication with students operating with a consumerist hermeneutics. These difficulties will be exacerbated by differences with regard to the place and value of the social production of knowledge.

In order to address such difficulties lecturers might be confronted by a number of temptations. The following temptations may be mentioned:

- Since students coming from a consumerist society are used to material that is neatly packaged, branded for easy recognition, and available for general consumption, there will always be the temptation to present material that is more accessible, less demanding and reduced in content. This will be exacerbated by the need for massification in higher education.

- The sheer volume of information available in any field of study creates the temptation to cover as much material as possible within a module. This leads almost necessarily to a mode of teaching where a quick survey is offered that seeks to cover a vast amount of material without any in-depth engagement. This can only lead to a further overload of claims to attention and a strengthening of an attitude of resistance among students in order to protect themselves from emotional drainage. Of course, this temptation may be countered by focusing on particular themes or case studies in more depth. However, a broadening of the students' horizons will then become more difficult.

- In a consumer society media claims are packaged in bite-size chunks in order to ensure that they are quite accessible and that the act of consumption can lead to instant gratification. This would tempt lecturers to offer course material in the same 
itemised mould, namely as a collection of loosely related cultural products that consumers of knowledge can engage with. As a result lecturers may well refrain from requiring from students to follow an extended argument in a longish article or a prescribed textbook. Students would, therefore, also find themselves unable to construct such an extended argument.

- The relatively passive mode of consuming cultural products (epitomised by television programmes) may well tempt lecturers not to require from students self-study tasks, library searches or exploratory research projects that would rely mainly on intellectual curiosity.

- Finally, the most significant temptation for lecturers would be to compete for the attention of students by creating a pleasurable experience that students would find entertaining enough to want to come to class. There would, of course, be nothing wrong with a creative and enjoyable classroom environment that captures the imagination of staff and students alike. One may even use suggestopedic teaching methodologies to enhance that and find ways of engaging students in classroom discussions. However, precisely through such creative teaching methods lecturers may easily condone a consumerist ethos, where the acquisition of knowledge becomes subservient to the pursuit of pleasure, happiness and consumer gratification. One problem with this style of lecturing is that teaching would find it difficult to compete with the entertainment industry, mega-sport events or the lucrative world portrayed by the advertising industry.

Drawing from my own experience as lecturer in the fields of Ethics and Theological Studies (but not as an expert in the field of education), one may also identify a number of strategies which may be used in order to assist students in deepening their engagement with knowledge products.

- One of the better ways to test a student's understanding of a prescribed text is to ask them to write an abstract of the argument of the text (if not already available in the text - another sign of the need for bite-size chunks and immediate access). This requires from a student to cover each section of the argument, to do justice to the author's own point of view, to pick up the essence of the argument, and sometimes also to read between the lines in order to identify the rhetorical thrust of a text. This exercise only works if the abstract is quite short (approximately 200 words) so 
that students cannot merely produce a summary of the text. This would help to counter a shallow engagement with a text.

- In addition, students may be asked to write notes on the text (with detailed page references) in which they have to demonstrate an in-depth engagement with the text - in the form of questions for clarification, comments and criticisms. One may add to that an assessment of the argument of the prescribed text.

- It is also possible to give students tasks where they have to discover a world of knowledge for themselves, where they have to do some detective work to find clues to unravel a particular problem through self-directed research. This would certainly involve internet searches (which can stimulate curiosity) but should not be limited to that. This strategy would help to counter a passive engagement with course material.

\section{Conclusion}

The hegemony imposed by any ideology is never complete. The tighter it is imposed the more vulnerable it becomes to voices of resistance and pluralising tendencies. Apartheid may serve as an apt example here, but it certainly applies to consumerism as well. As Vincent Miller argues, the explosion of agency that has accompanied the consumer culture precludes any turning back. The only way forward is through consumer culture, by embracing grassroots agency (cf. Miller, 2003:146-224). Among the affluent (who can afford to pay higher prices for certain products) politically correct purchasing ("political/ethical consumerism") expresses one form of exercising one's own buying power to effect policy changes. Likewise, consumers of cultural products are also creative agents who produce new meaning and exercise choices even as they receive and consume such cultural products. The victims of cultural imperialism are, therefore, never merely passive in their reception of such products; they appropriate such products in varied ways.12

12 John Fiske (2000:307) argues that the unemployed and the less affluent, too, may exercise considerable power through shopping. He explains that the hegemonic power of ideology is never complete and that resistance against consumerism is also found among those caught within the trap. He says:

Shopping is the crisis of consumerism: it is where the art and tricks of the weak can inflict most damage on, and exert most power over, the strategic interests of the powerful. 
This recognition of the role on consumer agency may well suggest that the only response to the passive shallow engagement that characterise a consumerist hermeneutics, is to deepen such agency through the subversive teaching practices sketched above. As most teachers would attest, there are indeed cases where students do pursue knowledge for its own sake (and not merely for the sake of obtaining a degree), where they actually become intrigued and excited with the insights that they have gained, where their curiosity leads them to go further than what was expected, where they wish to extend the frontiers of knowledge in a particular area. Such moments make the teaching profession worthwhile, especially when confronted with masses of unresponsive first-year students who have yet to unlearn the habits of a consumerist hermeneutics.

Moreover, as Ulrike Kistner (2007:82) observes, the relation between teaching and learning is a non-symmetrical relation of tutelage that becomes the site or network of ethical practices. The asymmetry involved may be open for abuse, but this is countered by a sense of vocation and the ethos of this vocation (and associated characteristics such as charisma and inspiration), which have been carefully guarded in teaching institutions for two and a half thousand years. It is in this relationship of tutelage that knowledge is perceived to be "more" than packaged and instrumentalised information - albeit that this is threatened by a consumerist hermeneutics. This, Kistner (2007:85) argues, explains the vehemence with which academics resist the incursions on teaching practices by the state and the market since the transfer of knowledge is incommensurable with institutional bureaucracy or monetary transactions. She (Kistner, 2007:91) insists that the transformative power of charisma is also evident in teaching:

Its manifestation in artistic creativity and in scientific inquiry pursued in university teaching are its prime exemplars in the realm of social practice, working as they do to keep the system from closing in on itself, and from dying from its own consequences.

Indeed the pursuit of knowledge for its own sake may serve as a reminder that there cannot be a self-instituting social order (or higher education institution). 


\section{List of references}

BAUMAN, Z. 2000. Liquid modernity. Oxford: Blackwell.

CONRADIE, E.M. 2009. Christianity and a critique of consumerism: a survey of six points of entry. Wellington: Bible Media.

DANIEL, L. 2005. Kid stuff: raising children in a consumer culture. Christian century, 122(1):23-27.

FISKE, J. 2000. Shopping for pleasure: malls, power and resistance. (In Schor, J.B. \& Holt, D.B., eds. The consumer society reader. New York: The New Press. p. 306-329.)

GORRINGE, T. 1994. Capital and the kingdom: theological ethics and economic order. Maryknoll: Orbis.

HIGGINS, J. 2007. "It's literacy, stupid!" Declining the Humanities in National Research Foundation (NRF) research policy. Journal of higher education in Africa, 5(1):95-112.

JANSEN, J. 2006. Accounting for autonomy. (In Pithouse, R., ed. Asinamali: university struggles in post-apartheid South Africa. Asmara: Africa World Press. p. 11-21.)

JONES, L.G. 1997. A thirst for God or consumer spirituality? Cultivating disciplined practices of being engaged by God. Modern theology, 13(1):126.

KAVANAUGH, J. 2006. Following Christ in a consumer society: the spirituality of cultural resistance. Maryknoll: Orbis.

KISTNER, U. 2007. Excess beyond excellence: the university beyond the balance sheet. Journal of higher education in Africa, 5(1):79-93.

KISTNER, U. 2008. Africanization in tuition: African National Education? Mediations, 24(1):90-109, Fall.

MAMDANI, M. 2007. Scholars in the marketplace: the dilemmas of neo-liberal reform at Makerere University, 1989-2005. Dakar: CODESRIA.

MCFAGUE, S. 2001. Life abundant: rethinking theology and economy for a planet in peril. Minneapolis: Fortress.

MILLER, V.J. 2003. Consuming religion: Christian faith and practice in a consumer culture. New York: Continuum.

PETERS, T.F. 1980. Fear, faith and the future. Minneapolis: Augsburg Publishing House.

READINGS, B. 1996. The university in ruins. Cambridge: Harvard University Press.

SCHOR, J.B. 2000. Towards a new politics on consumption. (In Schor, J.B. \& Holt, D.B., eds. The consumer society reader. New York: The New Press. p. 446-462.)

SCHOR, J.B. \& HOLT, D.B. 2000. The consumer society reader. New York: The New Press

SCHUDSON, M. 1998. Delectable materialism. (In Crocker, D.A. \& Linden, T., eds. Ethics on consumption: the good life, justice and global stewardship. Lanham: Rowman \& Littlefield. p. 249-268.)

STEWART, P 2007. Re-envisioning the academic profession in the shadow of corporate managerialism. Journal of higher education in Africa, 5(1):131147.

THOMAS, G. 2004. The cultural contest for our attention: observations on media, property, and religion. (In Schweiker, W. \& Mathewes, C., eds. Having: property and possession in religious and social life. Grand Rapids: Eerdmans. p. 271-295.) 
VALLY, S. 2007. Higher education in South Africa: market mill or public good? Journal of higher education in Africa, 5(1):17-28.

WEINBERG, G.S. 2007. Vying for legitimacy: academic vs. corporate culture. Journal of higher education in Africa, 5(1):61-77.

WEINBERG, G.S. \& KISTNER, U. 2007. Introduction: from ivory tower to market place: what future for the university in South Africa? Journal of higher education in Africa, 5(1):1-8.

\section{Key concepts:}

consumerism

hermeneutics

knowledge

university education

\section{Kernbegrippe:}

hermeneutiek

kennis

universiteitsopvoeding

verbruikerskultuur 